\title{
Platelet Factor 4 Modulates the Mitogenic Activity of Basic Fibroblast Growth Factor
}

\author{
John B. Watson, Sarah B. Getzler, and Deane F. Mosher \\ Departments of Medicine and Biomolecular Chemistry, University of Wisconsin-Madison, Madison, Wisconsin 53706
}

\begin{abstract}
Basic fibroblast growth factor (bFGF) has been shown to stimulate cell proliferation after vascular injury. The mitogenic activity of bFGF requires interactions with both a high affinity receptor and a cell-surface heparan sulfate proteoglycan. We tested the ability of platelet factor 4 (PF 4) and other platelet heparin-binding proteins to modulate bFGF-stimulated [ ${ }^{3} \mathrm{H}$ ] thymidine incorporation into fibroblasts. The supernatant of thrombin-stimulated platelets contained an inhibitor of bFGF-induced mitogenesis; this activity coeluted with PF 4 upon gel filtration, heparin-agarose, and ion-exchange chromatography. Purified thrombospondin and $\beta$-thromboglobulin did not inhibit the mitogenic activity of bFGF. PF 4 inhibited the activity of 5 pM bFGF with $50 \%$ inhibitory concentration of $75 \mathrm{nM}$. Purified PF 4 also inhibited the basal incorporation of $\left[{ }^{3} \mathrm{H}\right]$ thymidine into 3T3 fibroblasts and the increased $\left[{ }^{3} \mathrm{H}\right]$ thymidine incorporation occurring after wounding of a cell monolayer. PF 4 did not affect the mitogenic activity of serum. Inhibition of bFGF activity by PF 4 could be overcome by exogenous heparin or chondroitin-4-sulfate, suggesting that inhibition of mitogenesis is caused by binding of PF 4 to cell-surface glycosaminoglycans. These results indicate that an important role of PF 4 released at sites of vascular injury and platelet activation is to control cellular proliferation caused by the release of bFGF from ruptured cells. (J. Clin. Invest. 1994. 94:261-268.) Key words: platelet factor $4 \cdot$ fibroblast growth factor $\bullet$ heparan sulfate proteoglycan $\bullet$ atherogenesis - cytokine
\end{abstract}

\section{Introduction}

Atherosclerotic plaque formation is a complicated multistage process thought to involve vessel wall injury with subsequent disruption of the endothelium and exposure of the underlying intimal layers. According to the "response to injury" hypothesis of atherogenesis, endothelial injury acts as a signal for monocyte attraction and production of intimal cell mitogens $(1,2)$. Subsequent proliferation of the underlying smooth muscle and fibroblast cells along with foam cell formation are thought to be precursors of fibrous plaque formation. An understanding of how multiple cell growth regulators present at a site of vascular

Address correspondence to Deane F. Mosher, M.D., University of Wisconsin-Madison, 4459 Medical Science Center, 1300 University Avenue, Madison, WI 53706.

Received for publication 1 April 1993 and in revised form 2 February 1994.

J. Clin. Invest.

(C) The American Society for Clinical Investigation, Inc.

0021-9738/94/07/0261/08 \$2.00

Volume 94, July 1994, 261-268 injury are able to send an interpretable signal will assist in developing strategies for intervention in disease states such as atherogenesis or in therapeutic complications such as restenosis after coronary angioplasty (3).

Basic fibroblast growth factor (bFGF) ${ }^{1}$ has been implicated in the pathological overproliferation of the vessel wall during arteriosclerosis (4). Direct infusion of bFGF into the vascular wall leads to new capillary formation and proliferation of smooth muscle cells (5). Anti-bFGF antibodies can inhibit endogenous intimal cell proliferation after balloon catheter injury (6). Release of endogenous bFGF from injured medial smooth muscle cells or fibroblasts may contribute, therefore, to overgrowth and occlusion of the vessel lumen. In vivo, soluble heparin inhibits smooth muscle cell proliferation after injury, possibly by displacing endogenous bFGF bound to the arterial wall and bringing it into the general circulation where it can no longer stimulate proliferation at the site of injury (7).

Members of the FGF family signal through a specific transmembrane receptor with tyrosine kinase activity; mitogenic activity is also dependent on the presence of heparan sulfate proteoglycans or heparin $(8-10)$. The increase in mitogenic activity in the presence of heparin was first described for acidic FGF (10) and results from an increase in the binding of acidic FGF to what was characterized as the high affinity receptor (11, 12). Heparin also potentiates the activity of bFGF $(13,14)$. Recently, using heparan sulfate-deficient cell lines (9), undersulfated fibroblasts (8), or undersulfated myoblasts (15), it has been shown that high affinity binding of bFGF to its tyrosine kinase receptor requires heparin or heparan sulfates. The finding that an FGF tyrosine kinase receptor contains a heparin-binding region suggests that a ternary complex forms between the receptor, bFGF, and heparin (16). Kinetically this implies that the measured high affinity $K_{\mathrm{d}}$ for bFGF binding is a cooperative interaction among all members of the ternary complex (17). Disruption of one of the binding interaction could therefore influence others.

Platelet factor 4 (PF 4 ) is one of several platelet $\alpha$-granule proteins synthesized in the developing megakaryocyte and released at the site of vascular injury. The localization of PF 4 to the platelet $\alpha$-granule along with platelet-derived growth factor, transforming growth factor- $\beta$, thrombospondin, and $\beta$-thromboglobulin suggests that PF 4 may play a role in tissue repair processes. A number of functions have been described for PF 4 including growth inhibitory activity, antiheparin activity, chemotactic activity, antiangiogenic activity, and inhibition of megakaryocytopoesis (for review see reference 18). Many of the activities regulated by PF 4 are processes thought to be important for wound repair.

The purpose of this study was to examine systematically the ability of PF 4 and other platelet $\alpha$-granule proteins to

1. Abbreviations used in this paper: bFGF, basic fibroblast growth factor; PF 4, platelet factor 4; SP, sulfopropyl. 

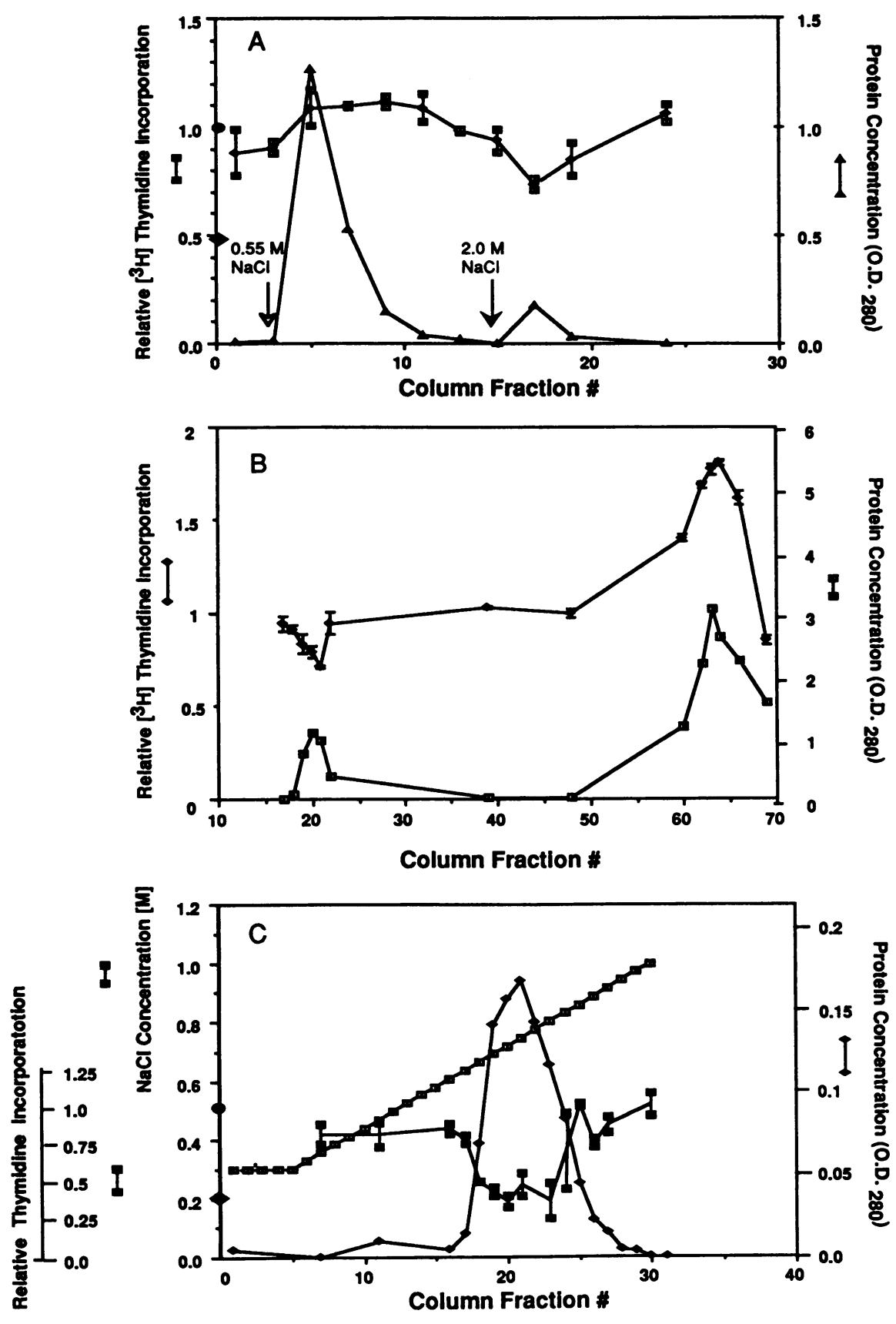

Figure 1. Copurification of a bFGF inhibitory activity and PF 4 . The releasate from thrombin-stimulated platelets was separated by chromatography on heparin-agarose $(A)$ or BioGel A 0.5 M (B) columns. The PF 4-containing peak from heparin-agarose was further separated on an SP column $(C)$. Column fractions were assayed for protein concentration and the ability to inhibit $\left[{ }^{3} \mathrm{H}\right]$ thymidine incorporation by $3 \mathrm{~T} 3$ fibroblasts in the presence of 5 pM bFGF. ( $A$ ) Purification on heparin-agarose. Thrombin-released proteins from 8 units of platelets were loaded onto a $10 \times 1.0$ (i.d.) $\mathrm{cm}$ heparin-agarose column; bound proteins were eluted first with $0.55 \mathrm{M}$ $\mathrm{NaCl}$ (open arrowhead) and then $2.0 \mathrm{M}$ $\mathrm{NaCl}$ (solid arrowhead). Fractions of $0.7 \mathrm{ml}$ were monitored for protein by absorbance at $280 \mathrm{~nm}$ (triangles) and modulation of $\left[{ }^{3} \mathrm{H}\right]-$ thymidine incorporation in the presence of 5 pM bFGF (open squares). $\left[{ }^{3} \mathrm{H}\right]$ Thymidine incorporation is expressed relative to the amount of incorporation in the presence of 5 pM bFGF. Both duplicate determinations are shown; the line is drawn through the average. The amount of $\left[{ }^{3} \mathrm{H}\right]$ thymidine incorporation in the absence of added bFGF is shown (solid diamonds) and in the presence of 5 pM FGF alone (solid circles); both duplicates are shown. ( $B$ ) Thrombin-released proteins from 4 units of platelets were loaded onto a 40 $\times 2.5$ (i.d.) $\mathrm{cm}$ column of Bio-Gel A $0.5 \mathrm{M}$ equilibrated in $150 \mathrm{mM} \mathrm{NaCl} / 20 \mathrm{mM}$ Tris, $\mathrm{pH} 7.4$, buffer containing $0.3 \mathrm{mM} \mathrm{CaCl}_{2}$, and fractions of $2.5 \mathrm{ml}$ were collected. Fractions were monitored for protein (squares) and modulation of $\left[{ }^{3} \mathrm{H}\right]$ thymidine incorporation as in $A$. (C) Purification of PF 4 on an SP column. The active fractions from the heparin-agarose column were repurified on a 7.5 $\mathrm{cm} \times 0.8-\mathrm{mm}$ (i.d.) $\mathrm{cm}$ SP-FPLC column and eluted with a continuous salt gradient from 0.3 to $1.0 \mathrm{M} \mathrm{NaCl}$ (open squares). Fractions were assayed for protein concentration (solid diamonds) and modulation of bFGF-stimulated $\left[{ }^{3} \mathrm{H}\right]$ thymidine incorporation (solid squares) as in $A$. For $\left[{ }^{3} \mathrm{H}\right]-$ thymidine incorporation assays, $10 \mu \mathrm{l}$ of each column fraction, along with concentrated $\mathrm{NaCl}$ or buffer to equalize salt concentrations and volume ( $350 \mu \mathrm{l}$ final volume), was added per $35-\mathrm{mm}$ well. modulate mitogenesis induced by bFGF. PF $4, \beta$-thromboglobulin, and thrombospondin bind to, and compete for, cell-surface heparan sulfate proteoglycans (19). We wanted to test whether competition for cell-surface heparan sulfate proteoglycans by these proteins changed the mitogenic activity of bFGF. Our results indicate that PF 4 is a specific inhibitor of bFGF-stimulated $\left[{ }^{3} \mathrm{H}\right]$ thymidine incorporation. Excess bFGF, heparin, or chondroitin-4-sulfate overcame the PF 4 inhibition of bFGF. Finally, it was found that PF 4 suppressed the baseline proliferation of serum-starved Swiss 3T3 cells, probably by inhibiting the activity of endogenously released FGF. Inasmuch as bFGF (7) and PF 4 (20) are colocalized in the subendothelial intima of damaged vessels, the inhibition of mitogenic activity of bFGF by PF 4 may be important in preventing pathological overproliferation of the vessel wall.

\section{Methods}

Platelets from the American Red Cross Blood Services, Badger Region, were washed and stimulated with thrombin as described (21). The supernatant of thrombin-stimulated platelets was purified by affinity chromatography on heparin-agarose (Sigma Immunochemicals, St. Louis, MO) or gel filtration on Bio-Gel 0.5 M (Bio-Rad Laboratories, Hercules, CA). Some experiments were done with PF 4 that was further purified on a sulfopropyl (SP) ion-exchange column (22). PF 4 purified on heparin-agarose was diluted to $0.3 \mathrm{M} \mathrm{NaCl}$ in $30 \mathrm{mM}$ Tris ( $\mathrm{pH} 7.4$ ) 


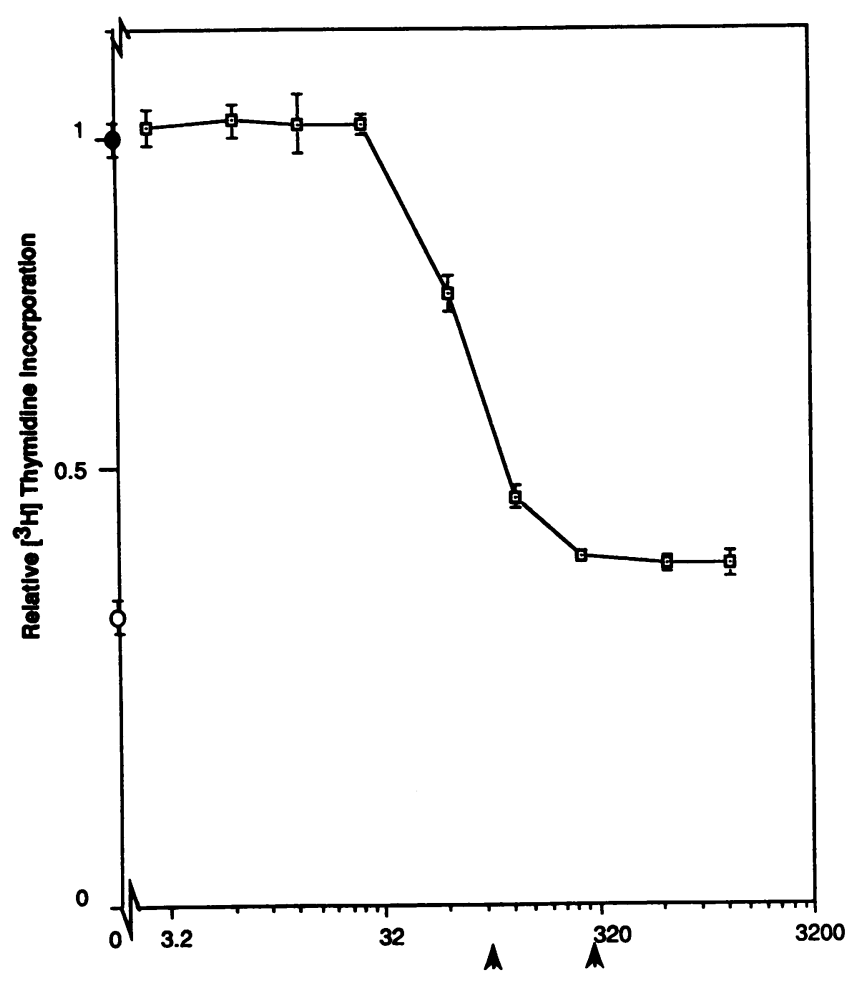

PF 4 Concentration ( $\mathrm{nM}$ )

Figure 2. Effects of different concentrations of PF 4 on the mitogenic activity of bFGF. Serum-starved Swiss 3T3 cells were treated with 5 pM bFGF alone (closed circle), buffer alone (open circle), or 5 pM bFGF and increasing concentrations of PF 4 (open squares). [ $\left.{ }^{3} \mathrm{H}\right]-$ Thymidine incorporation is expressed relative to the amount of incorporation in the presence of 5 pM bFGF. Inhibition of bFGF was detected as a decrease in $\left[{ }^{3} \mathrm{H}\right]$ thymidine incorporation. Values are the average of triplicates $\pm \mathrm{SE}$. Arrowheads indicate the concentrations of PF 4 used in Fig. 3.

and loaded in the same buffer onto an FPLC column (SP-5 PW; Waters Chromatography Division, Milford, MA). PF 4 eluted at $\sim 0.75 \mathrm{M}$ $\mathrm{NaCl}$ in a salt gradient from 0.3 to $1.0 \mathrm{M} \mathrm{NaCl}$ in $20 \mathrm{mM}$ Tris buffer. Protein concentration of column fractions was estimated both by $A^{280 n m}$ in a flow monitor and by using the BCA reagent (Pierce Chemical Co., Rockford, IL) with IgG as a standard. Fractions were also analyzed by SDS-PAGE.

Serum amyloid P-component purified from recalcified serum (23) was provided by Eliot Williams (University of Wisconsin-Madison). Thrombospondin was purified from fresh human platelets by heparinagarose affinity chromatography followed by gel filtration chromatography on Bio-Gel A $0.5 \mathrm{M}(21)$. $\beta$-Thromboglobulin eluted as a separate gel filtration peak during the purification of thrombospondin (21). $\beta$ Thromboglobulin was further purified on an SP-FPLC column as described above for PF 4, the only modification being that the buffer for the sample and gradient (starting) was at $0.15 \mathrm{M} \mathrm{NaCl}$, and the purified protein eluted at $\sim 0.5 \mathrm{M} \mathrm{NaCl}$. Protein concentrations were determined using the BCA reagent.

Recombinant bFGF, recombinant epidermal growth factor, and recombinant platelet derived growth factor ( $A B$ heterodimer) expressed in yeast were purchased from Upstate Biotechnology, Inc. (Lake Placid, NY). bFGF (17.5 kD) was stored at $4^{\circ} \mathrm{C}$ as a stock solution of $1 \mu \mathrm{g} /$ $\mu \mathrm{l}$ in Tris-buffered saline/0.1\% 3-[(3-cholamidopropyl) dimethylammonio]-1-propanesulfonate. Heparin $(\sim 10 \mathrm{kD})$ and chondroitin-4-sulfate were purchased from Sigma Immunochemicals and had been purified from porcine intestinal mucosa and bovine trachea, respectively. The concentration of bFGF as stated by the supplier was used to calcu- late the concentrations of bFGF after dilutions for experiments. The size of the PF 4 used for all calculations was the $32-\mathrm{kD}$ tetramer.

Swiss 3T3 cells were a gift from Alan Rapraeger (University of Wisconsin-Madison). Cells were split 1:3 twice a week in DMEM/5\% FBS. $2 \mathrm{~d}$ before performing $\left[{ }^{3} \mathrm{H}\right]$ thymidine incorporation assays, cells were plated in 24-well plates at $30-50 \%$ confluency in DMEM/5\% FBS and grown at $37^{\circ} \mathrm{C}$ in $5 \% \mathrm{CO}_{2}$ for $24 \mathrm{~h}$. Then, cells were serumstarved for $24 \mathrm{~h}$ in $0.32 \mathrm{ml}$ DMEM/0.2\% BSA. PF 4, other heparinbinding proteins, or buffer (to ensure equal volumes and salt concentrations) was added to cells just before bFGF or other growth factors. For experiments with heparin and chondroitin-4-sulfate, the glycosaminoglycans and PF 4 were preincubated with the cells for $1 \mathrm{~h}$ before the addition of bFGF. Cells were incubated for $18 \mathrm{~h}$ at $37^{\circ} \mathrm{C}$ in $5 \% \mathrm{CO}_{2}$ before addition of $2 \mu \mathrm{Ci} / \mathrm{ml}$ (final concentration) $\left[{ }^{3} \mathrm{H}\right]$ thymidine (New England Nuclear, Wilmington, DE), sp act $740 \mathrm{GBq} / \mathrm{mM}$. $6 \mathrm{~h}$ later, the cells were washed three times with $5 \%$ trichloroacetic acid and dissolved in $0.1 \mathrm{~N} \mathrm{NaOH}$ before counting in $10 \mathrm{ml}$ Biosafe II scintillation cocktail (Research Products International Corp., Mount Prospect, IL). All experiments were done at least twice with similar results. Experiments are reported as the mean \pm SEM or as mean with both duplicates shown. Student's $t$ test calculations were performed using StatView ${ }^{\mathrm{TM}}$ $512+$ (Brain Power Inc., Calabasas, CA).

Wounding experiments were performed by scraping a sterile Pasteur pipette tip from edge to edge twice perpendicularly within a well of a 35-mm dish (24). Cell counts were done with a hemocytometer.

\section{Results}

Copurification of PF 4 and bFGF inhibitory activity on heparinagarose, gel filtration, and SP columns. Platelet-released supernatant was loaded onto a 2-ml heparin-agarose column and

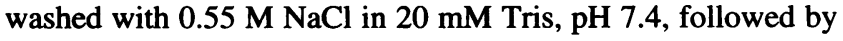
$2 \mathrm{M} \mathrm{NaCl}$ in $20 \mathrm{mM}$ Tris, $\mathrm{pH} \mathrm{7.4}$. The column fractions were assayed for $\mathrm{A}^{280 \mathrm{~nm}}$, and effects on bFGF-simulated $\left[{ }^{3} \mathrm{H}\right]$ thymidine incorporation were quantified (Fig. $1 A$ ). One protein peak, containing thrombospondin and $\beta$-thromboglobulin, eluted from heparin-agarose in the presence of $0.55 \mathrm{M} \mathrm{NaCl}$ (21). A second protein peak was eluted with $2.0 \mathrm{M} \mathrm{NaCl}$ and caused a decrease in $\left[{ }^{3} \mathrm{H}\right]$ thymidine incorporation by Swiss $3 \mathrm{~T} 3$ cells in the presence of 5 pM FGF. The second peak contained PF 4 that was a single homogeneous $8-\mathrm{kD}$ band, as determined by Coomassie brilliant blue staining of SDS-PAGE gels (data not shown).

When the supernatant of thrombin-stimulated platelets was separated by gel filtration, the first peak contained inhibitory activity in the bFGF-stimulated $\left[{ }^{3} \mathrm{H}\right.$ ] thymidine-uptake assay (Fig. $1 B$ ). SDS-PAGE (not shown) indicated that this peak contained thrombospondin and PF 4, presumably in complex with chondroitin-4-sulfate-bearing proteoglycan $(25,26)$.

The fractions eluting at $2 \mathrm{M} \mathrm{NaCl}$ from the heparin column (Fig. $1 A$ ) were pooled and further separated on an SP-FPLC column. PF 4 eluted at $\sim 0.75 \mathrm{M}$ salt from the SP-FPLC column (Fig. $1 C$, diamonds). When column fractions were examined for their effect on bFGF-stimulated $\left[{ }^{3} \mathrm{H}\right]$ thymidine incorporation, a single set of inhibitory fractions was found that coincided with the fractions that contained PF 4 (Fig. $1 C$, squares).

Concentration-dependent inhibition of bFGF-stimulated growth by $P F 4$. To quantify the inhibitory activity of PF 4, increasing concentrations of purified PF 4 were added to 3T3 fibroblasts in the presence of 5 pM bFGF. As shown in Fig. 2 , bFGF growth activity was inhibited with increasing PF 4 concentrations. The $50 \%$ inhibitory concentration $\left(\mathrm{IC}_{50}\right)$ was seen at a PF 4 tetramer concentration of $\sim 75 \mathrm{nM}$. This concentration is within the range (up to $160 \mathrm{nM}$ ) of PF 4 in serum after platelet activation (27). The inhibitory effect of PF 4 on 


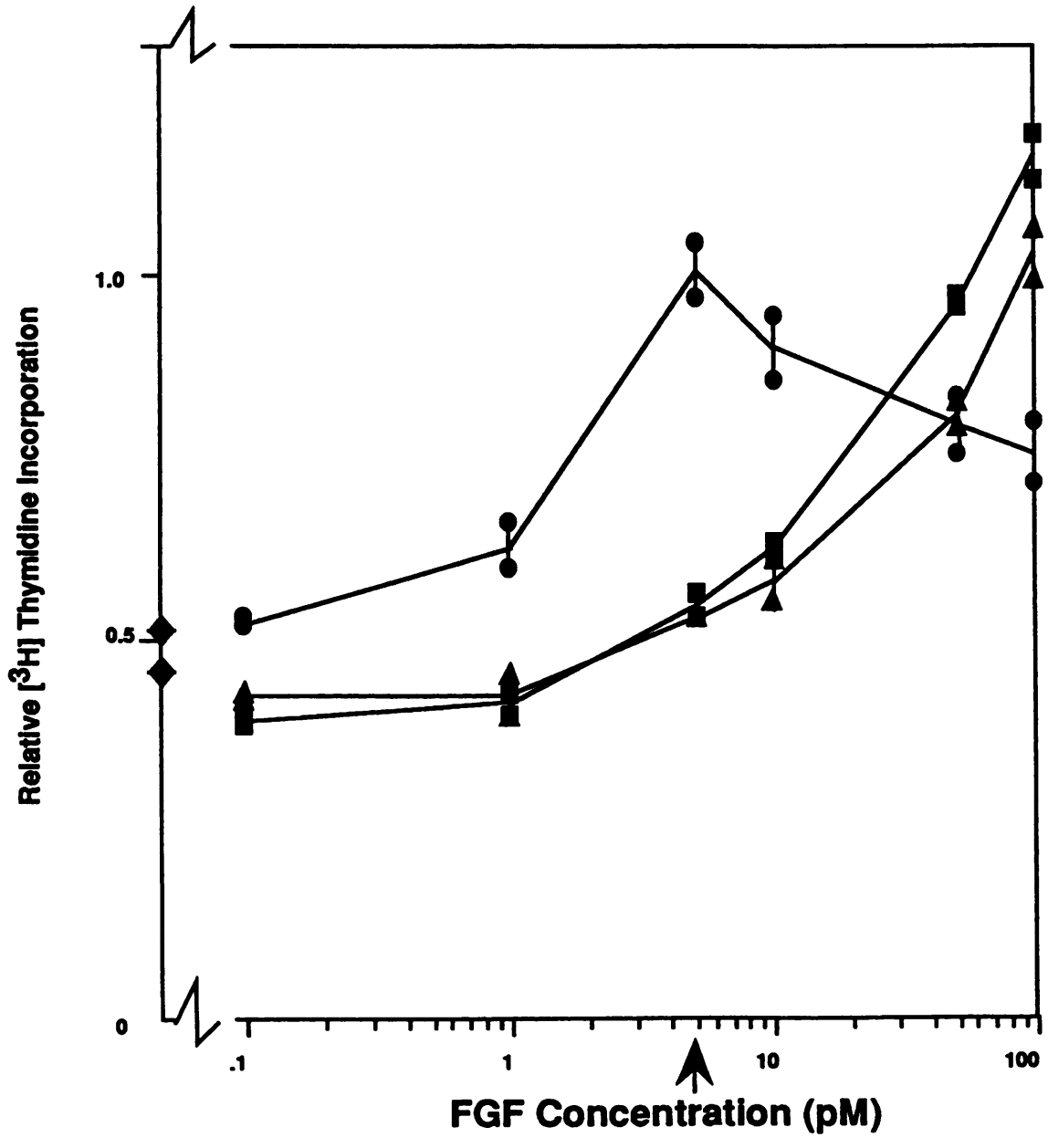

Figure 3. Effect of PF 4 on mitogenic activity in response to different concentrations of bFGF. Increasing concentrations of bFGF were added to wells containing $288 \mathrm{nM}$ PF 4 (solid triangles), $96 \mathrm{nM}$ PF 4 (solid squares), or buffer alone (solid circles). Duplicate values are plotted, and lines are drawn through the average of the duplicates. The arrow indicates 5 pM bFGF, the concentration used in the experiment shown in Fig. 2. $\left[{ }^{3} \mathrm{H}\right]$ Thymidine incorporation is expressed relative to the average seen with 5 pM bFGF alone (arrow). Baseline incorporation in the absence of added bFGF is also shown (solid diamonds, duplicates are shown). $\left[{ }^{3} \mathrm{H}\right]$ thymidine incorporation correlated with a similar inhibition of cell growth as quantified by cell counts. Starting with 8,000 cells and counting after $48 \mathrm{~h}$, final cell numbers (mean $\pm S E$, $n=4$ ) were: $24,500 \pm 1,600$ in the presence of 5 pM bFGF; $14,500 \pm 1,000$ for the no additions control; and 17,500 \pm 500 in the presence of $5 \mathrm{pM}$ bFGF and $450 \mathrm{nM}$ PF 4.

The inhibitory activity of PF 4 is overcome by excess bFGF. $\left[{ }^{3} \mathrm{H}\right]$ Thymidine incorporation in the presence of increasing concentrations of bFGF in the absence (closed circles) or presence of either 96 (closed squares) or $288 \mathrm{nM}$ (closed triangles) PF 4 is shown in Fig. 3. Maximal activity of recombinant yeast bFGF alone was found at 5 pM bFGF (Fig. 3, arrow). Higher concentrations of bFGF resulted in less $\left[{ }^{3} \mathrm{H}\right]$ thymidine incorporation. PF 4 at a concentration of 96 and $288 \mathrm{nM}$ (Fig. 2, arrowheads) shifted the activity curve for bFGF 10- and 25fold to the right, respectively.

Heparin or chondroitin-4-sulfate overcome PF 4 inhibition of $b F G F$. The effects of exogenous heparin and chondroitin4-sulfate on the inhibition of bFGF-stimulated $\left[{ }^{3} \mathrm{H}\right]$ thymidine incorporation by PF 4 are shown in Fig. 4. Heparin $(4.2 \mu \mathrm{g} /$ $\mathrm{ml}, \sim 0.42 \mu \mathrm{M})$ or chondroitin-4-sulfate $(4.2 \mu \mathrm{g} / \mathrm{ml})$ overcame the inhibition seen with $130 \mathrm{nM}$ PF 4 . Heparin or chondroitin4-sulfate alone had no effect on bFGF-induced mitogenesis.

Other heparin-binding proteins do not inhibit the mitogenic activity of $b F G F$. The effects of purified thrombospondin and $\beta$-thromboglobulin on bFGF-stimulated $\left[{ }^{3} \mathrm{H}\right]$ thymidine incorporation were examined at concentrations higher than these proteins when found in platelet releasate (28). Fig. 5 shows that only PF 4 was able to inhibit bFGF-stimulated $\left[{ }^{3} \mathrm{H}\right.$ ] thymidine incorporation. The $\beta$-thromboglobulin used in this experiment contains the four amino acids at the amino terminus that are associated with mitogenic activity (19). However, in the absence of bFGF, $\beta$-thromboglobulin caused at most a 1.2 -fold increase in $\left[{ }^{3} \mathrm{H}\right]$ thymidine incorporation (data not shown). Serum amyloid P-component, a potent heparin-binding protein in anticoagulation assays (29), also showed no effect.

PF 4 has less effect on the activities of other growth factors. To determine the specificity of PF 4 inhibition of $\left[{ }^{3} \mathrm{H}\right]$ thymidine incorporation, the effect of PF 4 on other growth factors was examined. Table I shows that 243 nM PF 4 did not significantly inhibit serum-stimulated $\left[{ }^{3} \mathrm{H}\right]$ thymidine incorporation or epidermal growth factor-stimulated $\left[{ }^{3} \mathrm{H}\right]$ thymidine incorporation. PF 4 inhibited incorporation due to platelet-derived growth factor by $37 \%$.

PF 4 inhibits $\left[{ }^{3} \mathrm{H}\right]$ thymidine incorporation by Swiss $3 T 3$ cells in the absence of added growth factors. The inhibition of bFGF-stimulated $\left[{ }^{3} \mathrm{H}\right]$ thymidine incorporation by PF 4 was consistent among experiments. In 10 experiments, $240 \mathrm{nM}$ PF 4 reduced bFGF-induced $\left[{ }^{3} \mathrm{H}\right]$ thymidine incorporation an average of $46 \pm 6 \%$, relative to that seen in the presence of $5 \mathrm{pM}$ bFGF alone (paired $t$ test, $P<0.005, n=10$; see Fig. $6 A$ ).

PF 4 also inhibited the baseline $\left[{ }^{3} \mathrm{H}\right.$ ] thymidine incorporation by serum-starved $3 \mathrm{~T} 3$ fibroblasts, i.e., incorporation in the absence of added growth factors. In the presence of PF 4 alone, 


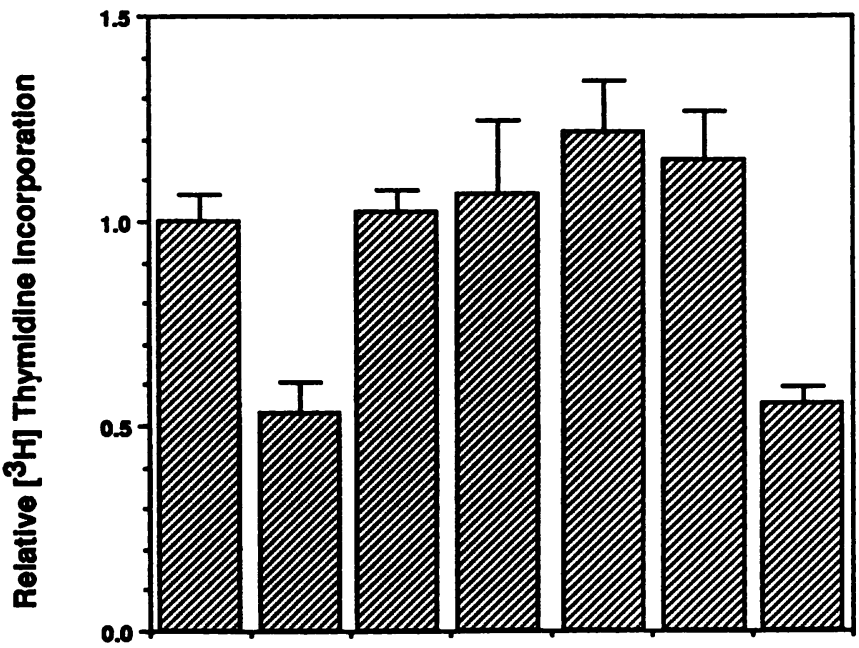

FGF ( 5 pM)

PF $4(0.13 \mu \mathrm{M})$

Heparin $(4.2 \mathrm{ug} / \mathrm{ml})$

Chondritin 4-Sulfate $(4.2 \mathrm{ug} / \mathrm{ml})$

$\begin{array}{ccc}+ & + & + \\ - & + & - \\ - & - & - \\ - & - & +\end{array}$

Figure 4. Effect of heparin and chondroitin-4-sulfate on PF 4 inhibition of bFGF. Heparin $(4.2 \mu \mathrm{g} / \mathrm{ml})$, chondroitin-4-sulfate $(4.2 \mu \mathrm{g} / \mathrm{ml})$, and/or $0.13 \mu \mathrm{M}$ PF 4 were added to 3 T3 fibroblasts $1 \mathrm{~h}$ before $5 \mathrm{pM}$ bFGF as indicated. $\left[{ }^{3} \mathrm{H}\right]$ Thymidine incorporation values are the average of triplicates $\pm \mathrm{SE}$ and are expressed relative to the $\left[{ }^{3} \mathrm{H}\right]$ thymidine incorporation in the presence of $5 \mathrm{pM}$ bFGF alone. $\left[{ }^{3} \mathrm{H}\right]$ thymidine incorporation was $27 \pm 3.6 \%$ of that seen with 5 pM bFGF. In contrast, the average amount of $\left[{ }^{3} \mathrm{H}\right]$ thymidine incorporation in the absence of any added cytokines (no additions) was $44 \pm 4 \%$ of that seen with 5 pM bFGF. The difference between $\left[{ }^{3} \mathrm{H}\right]$ thymidine incorporation in the presence of PF 4 alone and in the no additions controls was significant (paired $t$ test, $P<0.005, n=10$ ).

The inhibition of baseline incorporation by PF 4 was concentration dependent and occurred over a similar concentration range as the inhibition of bFGF by PF 4 (Fig. $6 \mathrm{~B}$ ). Since cell wounding has been shown previously to release endogenous bFGF (24), and Swiss 3T3 cells contain bFGF under the culture conditions used (30), we tested to see if PF 4 would inhibit the growth stimulated by cell wounding (Fig. $6 C$ ). The inhibition of thymidine incorporation in wounded cells was similar to that seen in serum-starved cells without wounding.

\section{Discussion}

Our laboratory has previously examined the binding of thrombospondin to cell-surface heparan sulfate proteoglycans (19,
31,32 ) and has shown, using competitive binding assays, that PF 4 and $\beta$-thromboglobulin compete for thrombospondin binding to cell-surface heparan sulfate proteoglycans (19). One consequence of this competition is blockage of the internalization of thrombospondin (19). Data showing that the activity of bFGF is dependent on the binding of heparin or heparan sulfate glycosaminoglycans $(8,9)$ led us to examine the ability of platelet heparin-binding proteins to inhibit the activity of bFGF.

PF 4 purified on a heparin column (Fig. $1 A$ ) or an SP-FPLC column (Fig. $1 C$ ) attenuated bFGF-stimulated $\left[{ }^{3} \mathrm{H}\right]$ thymidine incorporation. The sigmoidal inhibition curve, seen with increasing concentrations of PF 4 on attenuation of bFGF-stimulated growth (with an $\mathrm{IC}_{50}$ of $75 \mathrm{nM}$; Fig. 2), is similar to that published by Sato et al. (33) for displacement of bFGF by PF 4 from its high affinity cell binding site and our estimates of PF 4 required to inhibit cell-surface binding of thrombospondin (19). It is also approximate to the concentration of fluoresceinlabeled PF 4 needed for $50 \%$ saturation of cell-surface binding sites (Watson, J. B., and D. F. Mosher, manuscript in preparation). Further evidence that PF 4 inhibition of bFGF activity is a competitive phenomenon is indicated by evidence showing

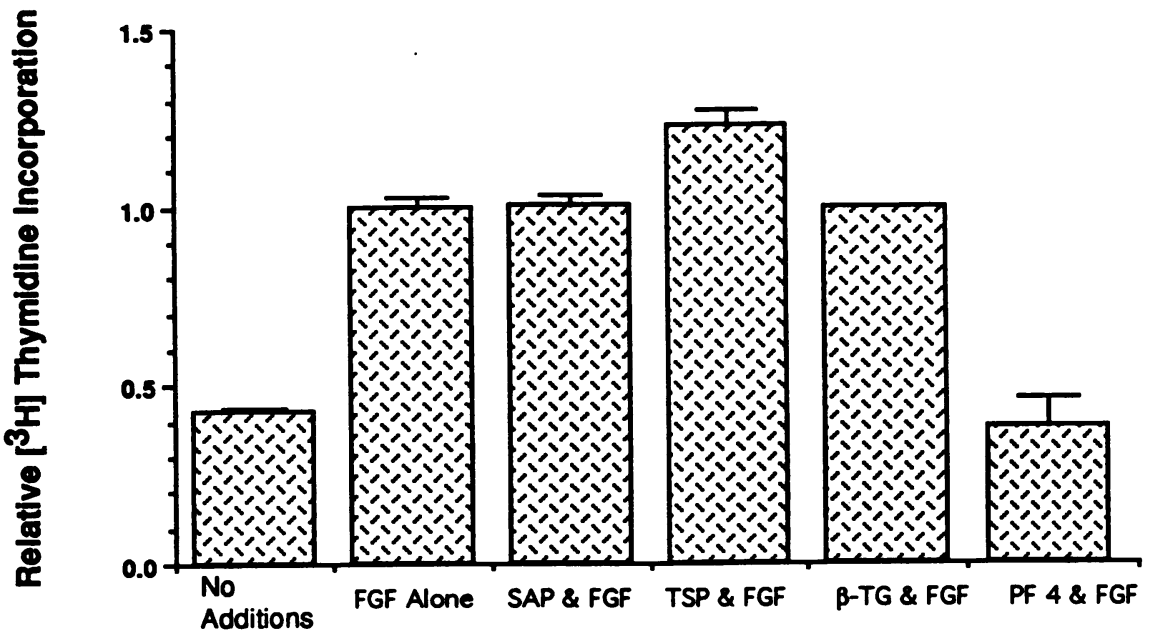

Figure 5. Effects of heparin-binding proteins on mitogenic effect of bFGF. Serum amyloid P-component protein $(S A P, 300 \mathrm{nM})$, thrombospondin (TSP, $60 \mathrm{nM}$ as a trimer), PF 4 ( $243 \mathrm{nM}$ tetramer), and $\beta$-thromboglobulin ( $\beta-T G, 900 \mathrm{nM}$ dimer $)$ were added before 5 pM bFGF. Results were normalized as a percentage of $\left[{ }^{3} \mathrm{H}\right]$ thymidine incorporation relative to $5 \mathrm{pM}$ bFGF alone. The $\beta$-TG result was from a separate experiment. Values are either the average of triplicates \pm SE or the average of duplicates with both values plotted (for $\beta$-TG). 
Table I. Effect of PF 4 on Other Growth Factors

\begin{tabular}{cc}
\hline Growth stimulus & $\begin{array}{c}\left.\text { Relative }{ }^{3} \mathrm{H}\right] \text { thymidine incorporation } \\
(\% \text { of control) }\end{array}$ \\
\hline bFGF & $36 \pm 1.9$ \\
EGF & $91 \pm 3.3$ \\
PDGF & $73 \pm 2.6$ \\
FBS & $94 \pm 1.6$ \\
\hline
\end{tabular}

Swiss $3 \mathrm{~T} 3$ cells were treated with or without $243 \mathrm{nM}$ PF 4 and either 400 pM EGF, $1 \mathrm{nM}$ PDGF, 5 pM bFGF, or 10\% FBS. Values are expressed as the relative $\left[{ }^{3} \mathrm{H}\right]$ thymidine incorporation (mean $\pm \mathrm{SE}, n=3$ ) in response to the growth stimulus in the presence versus absence of PF 4.

that increasing concentrations of bFGF were able to overcome the inhibitory activities of increasing concentrations of PF 4 (Fig. 3 ). In contrast to the results with PF $4, \beta$-thromboglobulin and thrombospondin at concentrations greater than those found in serum did not inhibit mitogenesis due to bFGF (Fig. 5). bFGF has a higher affinity for some sequences within the saccharide component of heparan sulfate proteoglycans than others $(34,35)$. These sequences, or heparin sequences that specifically bind the FGF receptor (see below), may bind PF 4 with a higher affinity than thrombospondin or $\beta$-thromboglobulin and explain the specificity of PF 4.

Heparin, but not chondroitin-4-sulfate, can substitute for cell-surface heparan sulfate in mediating bFGF binding to its tyrosine kinase receptor (9). In this study, exogenously added heparin and chondroitin-4-sulfate resulted in a loss of the inhibitory activity of PF 4 (Fig. 4). This result implies that the increase in $\left[{ }^{3} \mathrm{H}\right]$ thymidine incorporation seen in the presence of the glycosaminoglycans and PF 4 (Fig. 4) is due to the neutralization of the inhibitory effect of PF 4 and not superinduction of bFGF activity in the presence of the added heparin.

PF 4 binds with higher affinity to heparan sulfates than to chondroitin sulfates $(25,26)$ and is displaced from the chondroitin sulfate carrier if heparan sulfate glycosaminoglycans
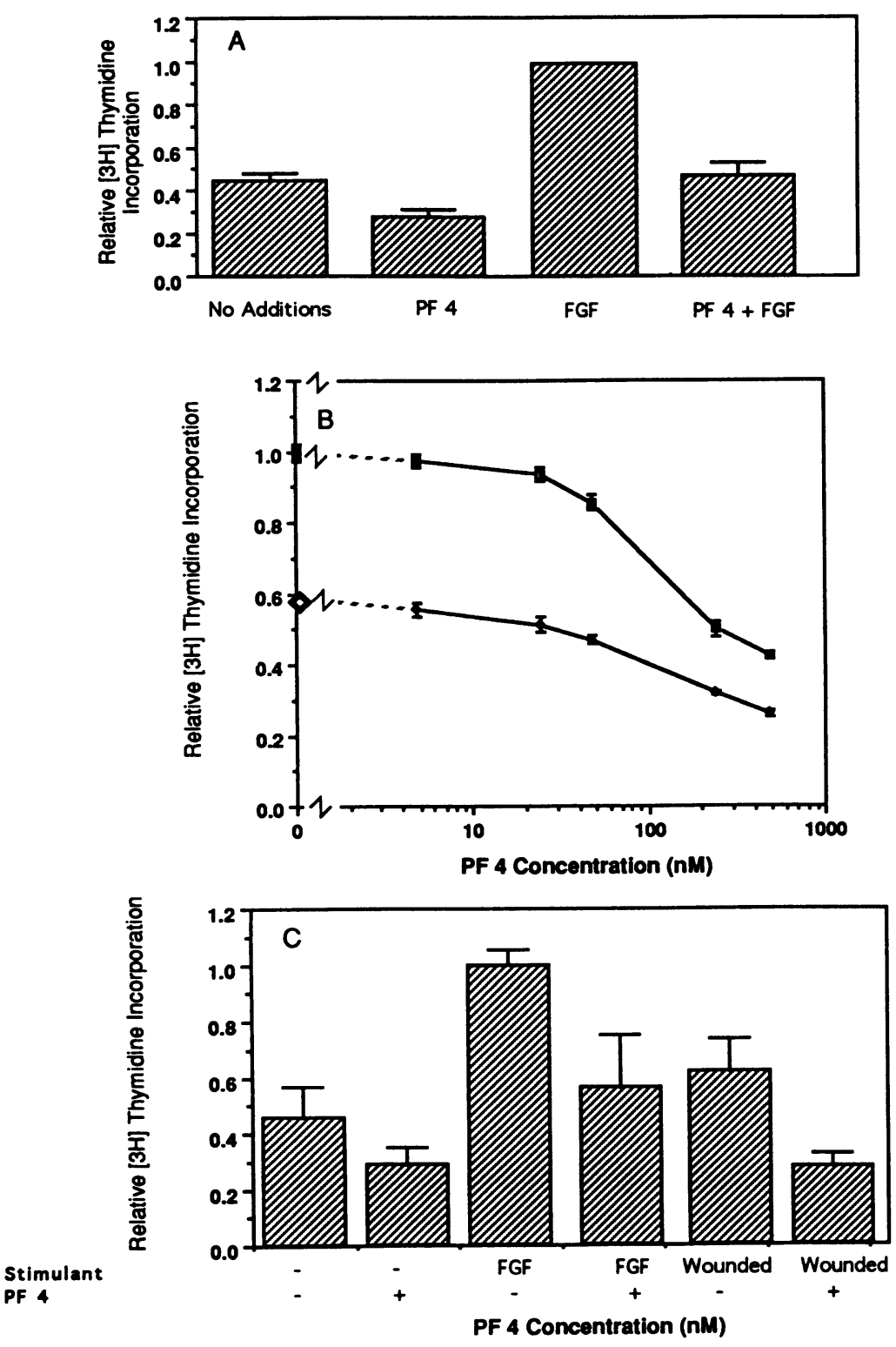

Figure 6. Effect of PF 4 on $\left[{ }^{3} \mathrm{H}\right]$ thymidine incorporation by Swiss 3T3 cells in the absence of added growth factors. $(A)\left[{ }^{3} \mathrm{H}\right]$ Thymidine incorporation in the absence (No Additions) or presence of either $243 \mathrm{nM}$ PF 4 or 5 pM FGF, or both, is expressed relative to that seen in the presence of bFGF alone. Values for no additions, PF 4 alone, and PF $4+$ bFGF are the average of 10 experiments \pm SE. $(B)$ Relative $\left[{ }^{3} \mathrm{H}\right]$ thymidine incorporation seen with increasing concentrations of PF 4 in the presence (open squares) or absence (closed diamonds) of 5 pM bFGF. The amount of $\left[{ }^{3} \mathrm{H}\right]$ thymidine incorporation in the presence of 5 pM FGF alone (closed rectangle) or no additions (open diamond) is shown. Values are the average of triplicates \pm SE. $(C)$ Stimulant was $5 \mathrm{pM}$ bFGF or wounding of monolayers by scraping, with or without $243 \mathrm{nM}$ PF 4 . Values are relative $\left[{ }^{3} \mathrm{H}\right]$ thymidine incorporation by Swiss $3 \mathrm{~T} 3$ cell$\mathrm{s} \pm \mathrm{SE}$. 
are present (26). We found that the chondroitin sulfate-PF 4 complex from platelets inhibited bFGF-stimulated $\left[{ }^{3} \mathrm{H}\right]-$ thymidine incorporation (Fig. $1 B$ ). This indicates that PF 4 can also dissociate from the carrier and bind to the cell-surface heparan sulfate proteoglycan important for the mitogenic activity of bFGF. The binding of purified PF 4 to endothelial cells has been described by Rybak et al. (36), who reported a $K_{d}$ of $700 \mathrm{nM}$ and $9 \times 10^{7}$ sites/cell for the binding of tetrameric ${ }^{125}$ I-labeled PF 4 to bovine aortic endothelial cells in suspension. In contrast, only $5 \times 10^{5}$ thrombospondin sites were reported using the same cell type (19). This is consistent with our finding that PF 4 and thrombospondin vary in their ability to inhibit bFGF activity.

PF 4 was specific in its high potency for inhibiting bFGF compared with other growth factors (Table I). PF 4 had some inhibitory activity towards PDGF, similar to the 50\% inhibition of PDGF-stimulated growth seen with protamine sulfate (37). Inhibition of sulfation by chlorate has been shown to decrease PDGF-stimulated growth of smooth muscle cells by $30 \%$ (38). It is interesting to speculate that since PDGF also binds heparin (39-41) cell-surface heparan sulfates may play a role in regulating the activity of PDGF similar to that seen with bFGF.

There are at least two mechanisms by which PF 4 could inhibit bFGF activity. First, since the interaction of bFGF with its high affinity receptor is dependent on the binding of bFGF to heparan sulfates $(8,9)$, it is possible that PF 4 acts by disrupting bFGF-heparan sulfate binding. A second potential mechanism for PF 4 inhibition of bFGF is to disrupt the binding of heparan sulfate to the second immunoglobulin domain of the FGF type 1 receptor (16). The latter possibility is supported by data showing that the heparin-binding region of PF 4 is more effective at displacing bFGF from its high affinity (tyrosine kinase receptor) sites than from cell-surface heparan sulfate proteoglycans (42).

bFGF is produced by a large number of cell types including, in one study, all fibroblast cells tested (43). Our finding that PF 4 inhibits both baseline mitogenesis and the increased mitogenesis caused by wounding (Fig. 6) indicates that PF 4 is inhibiting endogenously produced FGF. The wounding experiment seems highly pertinent to in vivo situations. Both bFGF (7) and PF 4 (20) are found in the subendothelial intima of the injured vessel wall, an environment that would contain the contents of both ruptured damaged cells and stimulated platelets. Thus, activated platelets, by secreting PF 4, may serve to downregulate mitogenesis due to FGF released from damaged cells.

\section{Acknowledgments}

This study was supported by National Institutes of Health grants HD07118 and HL-29586.

\section{References}

1. Ross, R. 1993. Atherosclerosis: a defense mechanism gone awry. Am. J. Pathol. 143:987-1002.

2. Ross, R. 1986. The pathogenesis of atherosclerosis - an update. N. Engl. J. Med. 314:488-500.

3. DeFeudis, F. V. 1991. Coronary atherosclerosis: current therapeutic approaches and future trends. Life Sci. 49:689-705.

4. Lindner, V., D. A. Lappi, A. Baird, R. A. Majack, and M. A. Reidy. 1991. Role of basic fibroblast growth factor in vascular lesion formation. Circ. Res. 68:106-113.

5. Cuevas, P., A. M. Gonzalez, F. Carceller, and A. Baird. 1991. Vascular response to basic fibroblast growth factor when infused onto the normal adventitia or into the injured media of the rat carotid artery. Circ. Res. 69:360-369.

6. Lindner, V., and M. A. Reidy. 1991. Proliferation of smooth muscle cells after vascular injury is inhibited by an antibody against basic fibroblast growth factor. Proc. Natl. Acad. Sci. USA. 88:3739-3743.

7. Lindner, V., N. E. Olson, A. W. Clowes, and M. A. Reidy. 1992. Inhibition of smooth muscle cell proliferation in injured rat arteries. Interaction of heparin with basic fibroblast growth factor. J. Clin. Invest. 90:2044-2049.

8. Rapraeger, A. C., A. Kru f ka, and B. B. Olwin. 1991. Requirement of heparan sulfate for bFGF-mediated fibroblast growth and myoblast differentiation. Science (Wash. DC). 252:1705-1708.

9. Yayon, A., M. Klagsbrun, J. D. Esko, P. Leder, and D. M. Ornitz. 1991. Cell surface, heparin-like molecules are required for binding of basic fibroblast growth factor to its high affinity receptor. Cell. 64:841-848.

10. Thornton, S. C., S. N. Mueller, and E. M. Levine. 1983. Human endothelial cells: use of heparin in cloning and long-term serial cultivation. Science (Wash. DC). 222:623-625

11. Kaplow, J. M., F. Bellot, G. Crumley, C. A. Dionne, and M. Jaye. 1990. Effect of heparin on the binding affinity of acidic FGF for the cloned human FGF receptors, flg and bek. Biochem. Biophys. Res. Commun. 172:107-112.

12. Schreiber, A. B., J. Kenney, W. J. Kowalski, R. Friesel, T. Mehlman, and T. Maciag. 1985. Interaction of endothelial cell growth factor with heparin: characterization by receptor and antibody recognition. Proc. Natl. Acad. Sci. USA. 82:6138-6142.

13. Damon, D. H., P. A. D'Amore, and J. A. Wagner. 1988. Sulfated glycosaminoglycans modify growth factor-induced neurite outgrowth in PC12 cells. J. Cell. Physiol. 135:293-300.

14. Neufeld, G., D. Gospodarowicz, L. Dodge, and D. K. Fujii. 1987. Heparin modulation of the neurotropic effects of acidic and basic fibroblast growth factors and nerve growth factor on PC12 cells. J. Cell. Physiol. 131:131-140.

15. Olwin, B. B., and A. Rapraeger. 1992. Repression of myogenic differentiation by aFGF, bFGF, and K-FGF is dependent on cellular heparan sulfate. J. Cell Biol. 118:631-639.

16. Kan, M., F. Wang, J. Xu, J. W. Crabb, J. Hou, and W. L. McKeehan. 1993. An essential heparin-binding domain in the fibroblast growth factor receptor kinase. Science (Wash. DC). 259:1918-1921.

17. Nugent, M. A., and E. R. Edelman. 1992. Kinetics of basic fibroblast growth factor binding to its receptor and heparan sulfate proteoglycan: a mechanism for cooperactivity. Biochemistry. 31:8876-8883.

18. Zucker, M. B., and I. R. Katz. 1991. Platelet factor 4: production, structure, and physiologic and immunologic action. Proc. Soc. Exp. Biol. Med. 198:693702.

19. Murphy-Ullrich, J. E., and D. F. Mosher. 1987. Interactions of thrombospondin with endothelial cells: receptor-mediated binding and degradation. J. Cell Biol. 105:1603-1611.

20. Goldberg, I. D., M. B. Stemerman, and R. I. Handin. 1980. Vascular permeation of platelet factor 4 after endothelial injury. Science (Wash. DC). 209:611-612.

21. Murphy-Ullrich, J. E., and D. F. Mosher. 1985. Localization of thrombospondin in clots formed in situ. Blood. 66:1098-1104.

22. Medici, I., A. Di Martino, G. Cella, L. Callegaro, and M. Prosdocimi. 1989. Improved method for purification of human platelet factor 4 by affinity and ion-exchange chromatography. Thromb. Res. 54:277-287.

23. Meyer, K., R. Smith, and E. C. Williams. 1987. Inhibition of fibrin polymerization by serum amyloid $\mathrm{P}$ component and heparin. Thromb. Haemostasis. 57:345-348.

24. Sato, Y., and D. B. Rifkin. 1988. Autocrine activities of basic fibroblast growth factor: regulation of endothelial cell movement, plasminogen activator synthesis, and DNA synthesis. J. Cell Biol. 107:1199-1205.

25. Handin, R. I., and H. J. Cohen. 1976. Purification and binding properties of human platelet factor four. J. Biol. Chem. 251:4273-4282.

26. Luscombe, M., S. Marshall, D. S. Pepper, and J. J. Holbrook. 1981. The transfer of platelet factor $\mathbf{4}$ from its proteoglycan carrier to natural and synthetic polymers. Biochim. Biophys. Acta. 678:137-142.

27. Files, J. C., T. W. Malpass, E. K. Yee, J. L. Ritchie, and L. A. Harker. 1981. Studies of human platelet alpha-granule release in vivo. Blood. 58:607618.

28. Mosher, D. F., D. M. Pesciotta, J. C. Loftus, and R. M. Albrecht. 1985 Secreted alpha granule proteins: the race for receptors. In Platelet Membrane Glycoproteins. J. N. George, D. R. Phillips, and A. T. Nurden, editors. Plenum Publishing Corp., New York. 171-191.

29. Williams, E. C., B. J. Huppert, and S. Asakura. 1992. Neutralization of the anticoagulant effects of glycosaminoglycans by serum amyloid P component: comparison with other plasma and platelet proteins. J. Lab. Clin. Med. 120:159167.

30. McNeil, P. L., L. Muthukrishnan, E. Warder, and P. A. D'Amore. 1989. Growth factors are released by mechanically wounded endothelial cells. J. Cell Biol. 109:811-822.

31. Sun, X., P. R. Kaesberg, J. Choay, J. Harenberg, W. B. Ershler, and D. F. Mosher. 1992. Effects of sized heparin oligosaccharide on the interactions 
of Chinese hamster ovary cell with thrombospondin. Semin. Thromb. Hemostasis. 18:243-251.

32. Sun, X., D. F. Mosher, and A. Rapraeger. 1989. Heparan sulfate-mediated binding of epithelial cell surface proteoglycan to thrombospondin. J. Biol. Chem. 264:2885-2889.

33. Sato, Y., M. Abe, and R. Takaki. 1990. Platelet factor 4 blocks the binding of basic fibroblast growth factor to the receptor and inhibits the spontaneous migration of vascular endothelial cells. Biochem. Biophys. Res. Commun. 172:595-600.

34. Tyrrell, D. J., M. Ishihara, N. Rao, A. Horne, M. C. Kiefer, G. B. Stauber, L. H. Lam, and R. J. Stack. 1993. Structure and biological activities of a heparinderived hexasaccharide with high affinity for basic fibroblast growth factor. $J$. Biol. Chem. 268:4684-4689.

35. Turnbull, J. E., D. G. Fernig, Y. Ke, M. C. Wilkinson, and J. T. Gallagher 1992. Identification of the basic fibroblast growth factor binding sequence in fibroblast heparan sulfate. J. Biol. Chem. 267:10337-10341.

36. Rybak, M. E., M. A. Gimbrone, P. F. Davies, and R. I. Handin. 1989. Interaction of platelet factor four with cultured vascular endothelial cells. Blood. 73:1534-1539.

37. Huang, J. S., J. Nishimura, S. S. Huang, and T. F. Deuel. 1984. Protamine inhibits platelet derived growth factor receptor activity but not epidermal growth factor activity. J. Cell. Biochem. 26:205-220.

38. Higashiyama, S., J. A. Abraham, and M. Klagsbrun. 1993. Heparin-binding
EGF-like growth factor stimulation of smooth muscle cell migration: dependence on interactions with cell surface heparan sulfate. J. Cell Biol. 122:933-940.

39. Fager, G., G. Camejo, U. Olsson, G. Ostergren-Lunden, and G. Bondjers. 1992. Heparin-like glycosaminoglycans influence growth and phenotype of human arterial smooth muscle cells in vitro. II. The platelet-derived growth factor Achain contains a sequence that specifically binds heparin. In Vitro Cell. \& Dev. Biol. 28A:176-180.

40. Khachigian, L. M., and C. N. Chesterman. 1992. Synthetic peptides representing the alternatively spliced exon of the platelet-derived growth factor Achain modulate mitogenesis stimulated by normal human serum and several growth factors. J. Biol. Chem. 267:7478-7482.

41. Khachigian. L. M., D. A. Owensby, and C. N. Chesterman. 1992. A tyrosinated peptide representing the alternatively spliced exon of the platlet-derived growth factor A-chain binds specifically to cultured cells and interferes with binding of several growth factors (published erratum appears in J. Biol. Chem. 1992. 267:6449). J. Biol. Chem. 267:1660-1666.

42. Sato, Y., M. Waki, M. Ohno, M. Kuwano, and T. Sakata. 1993. Carboxylterminal heparin-binding fragments of platelet factor 4 retain the blocking effect on the receptor binding of basic fibroblast growth factor. Jpn. J. Cancer Res. 84:485-488.

43. Moscatelli, D., M. Presta, J. Joseph-Silverstein, and D. B. Rifkin. 1986. Both normal and tumor cells produce basic fibroblast growth factor. J. Cell. Physiol. 129:273-276. 